\title{
EREG Gene Product
}

National Cancer Institute

\section{Source}

National Cancer Institute. EREG Gene Product. NCI Thesaurus. Code C118409.

A protein encoded by the EREG gene. 